\title{
Critical Discourse Analysis in Media Studies: A Review Research on Its Application in Indonesian Context
}

\author{
Anwar Anwar ${ }^{1}$, Asri Laraswati ${ }^{2}$, and Ridhani Ridhani ${ }^{3}$ \\ ${ }^{1}$ U-RAISE Academy, Pekanbaru, Indonesia \\ ${ }^{2}$ Applied Linguistics Center, Pekanbaru, Indonesia \\ ${ }^{2}$ Applied Linguistics Center, Pekanbaru, Indonesia \\ anwartheauthor@gmail.com
}

\begin{abstract}
ARTICLE HISTORY
Received : 7 February 2020

Revised : 25 February 2020

Accepted : 26 February 2020
\end{abstract}

\section{KEYWORDS}

Discourse Analysis

Critical Discourse Analysis (CDA)

Application

Review Research

Communication

\begin{abstract}
This research examines the field of discourse analysis which has popularity in the media field and communication studies. The research is focused on the application of critical discourse analysis (CDA) in Indonesia. This study is especially interested in examining CDA's variety of approaches. The goal of this review research is to discover and to know the role of CDA in the hidden ideologies in the media of discourse studies. The data in this study is on ten selected article journals to clarify the methods, ways, and to find in which CDA has been used in understanding social and educational phenomena. This study determined three themes in critical discourse analysis application, i.e. economic, political, and social contexts.
\end{abstract}

\section{Introduction}

At least ten years ago, 'discourse analysis' has become a contemporary term in linguistics. Hanks gave a statement; he has defined discourse as "it is language-in-action, and investigating it requires attention to both language and action" (Hanks, 1996). Initially, CDA had existed since 1952 when Zellig Harris wrote an article entitled Discourse Analysis published in the Language journal. Only then did the linguist of the 1970s realize the importance of discourse and text analysis of language role in the structuring of power relations in society.

Discourse studies is a field of an interdisciplinary between linguistic, psychology, poetics and social sciences the focused on the analysis of discourse, the systematic theory and then various context. It has developed from similar problem and interest be an extension in these disciplines. So, with discourse studies will make related to the fundamental similarity on discourse, object, forms in use of language and the communicative context.

Besides, one of strongest influencing researcher is Teun van Dijk as the author of The Handbook of Discourse Analysis (1985) and as a Dutch linguist is generally believed as the "founding father" from the contemporary of the study of discourse. In actuality, discourse studies have already been talked as a field of study in the 1970s. It has been developed until this period with many kinds and a branch of it. Discourse is focused on language use in sentences and the interaction between speaker and auditor or writer and reader, in a particular situation (Nordquist, 2017).
Moreover, "DA provides a basic methodology to describes and analyze how the structure and content of the textencode ideas and the relationships among the ideas itself that are present in the text, systematically" (Hamuddin, 2015).

Generally, discourse analysis concerns on language use between a group of people. It will analyze based on the writing from many others to specify usage. According to Discourse has two critical components of the news media, such as the news story and process when producing text. Accordingly, Fairclough's see on the language media analysis as "We need to analyze the media language as discourse, then the linguistic analysis of media should be part of the discourse analysis of media" (Fairclough, 2013). Bell has stated that discourse is in the electronic distribution for the future of writing (Smith \& Bell, 2007). So, "Discourse Analysis" is a field on applied linguistic that analyze the language use of the interaction with speaker and listener or writer and reader.

Strangely, talking and communicating seems to ignore each other as fields of research despite their common interest in text. This was noted by Van Dijk (2011), as the prominent discourse analysis practitioner found that the essence of messages actually receives little attention in mass communication research. Carbaugh (2007) even put forward that "the field of intercultural communication has been criticized for failing to produce studies which focus on actual practices of communication, especially of intercultural encounters." Much like how homogeneity of variables is desired in classroom practices, people in general encounter problems in communicating because the same expression and the same word are likely to have 
different meanings in different contexts or even with different tones. While the variability of the meaning of messages is not fundamentally troublesome, it does play the role as a threat to secure communication (Brown, 1995). This issue is also exacerbated with the advent of technology, as the underspecification or vagueness of word meaning may be increased with the rapid evolution of people's creativity with morphology (Derin et al., 2019). Thus, this study feels the necessity to contribute to the body of literature of critical discourse analysis to address the gap in communication research.

\section{Literature Review}

\subsection{Theory and Approaches to Critical Discourse Analysis (CDA)}

There is one interdisciplinary of discourse analysis, called Critical Discourse Analysis (CDA). CDA is a required field because there is an essential aspect of textual understanding is the identification of the topics of the discourse. Van Dijk (1985) has stated what CDA is focusing on this field starts from choosing the problem from suffering person or people and group, a social problem that happens. Analyze or examine who are responsible, have power and those who have the opportunity to solve such a problem.

On the other hand, Wodak (2001) has advocated CDA as a drawing of political action consequences of one's aspiration paired with a serious motive. Besides, Fairclough \& Kress (1993) defined it too about CDA as the description and theorization of a social process that rise to text production and structures and processes of social in-group then, make meanings for the interaction with text (Yunira et al., 2019).

The function of discourse field for the community is to provide real awareness (explicit awareness) for their role. This thinking comes from that science is 'value-free'. Critical Discourse Research (CDR) must meet the following prerequisites, to be effective in achieving its objectives, namely:

a. Because it includes the marginal research, CDR must be better than other researches to be accepted.

b. Its primary focus is on political and social issues, rather than the current paradigm and fashions.

c. Empirically, critical analysis of common multidisciplinary social problems.

d. Not only explain the structure of discourse, but it tries to clarify the notion of social interaction and especially on social structure.

Mainly, the CDA focuses on discourse structures that are created, confirm, legitimize, reproduce, or challenge the power relations and domination in society. Fairclough \& Kress (1993) established the main principles in CDA to be what is shown on Figure 2.2.1.
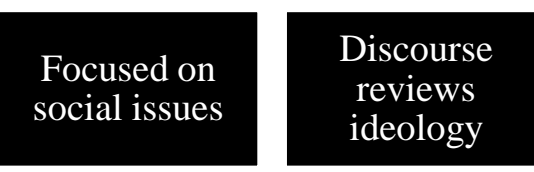

The power

relationship is

discursive

Figure 2.1.1 Principles of Critical Discourse Analysis

\subsection{Fairclough's Theory of Social Discourse}

This social theory of discourse has a goal for analyzing the social and politic events in our community and life. Norman Fairclough declares that "language use in society is a form of social practice rather than an individual activity" (Fairclough, 1992). This statement is correlated with the social group practising their economic or politic activities that contain an essential proposition for their commercial or social practice and refer to the presence of the new ideology.

Afterwards, Norman Fairclough suggested some principles as a social practice. There are three principles of discourse:

a. Constitutive and constituted. Discourse is contributed to making and reflecting on social structures.

b. Social Practice. It will make a social identity and a social relation in a group of people.

c. Knowledge and belief. It was contributed to the knowledge system and understanding as an identity in language use.

Thereupon, with this theory, Norman Fairclough has stated some dimensional model of Critical Discourse Analysis in three types, such as content a text, discursive practice and social practice. In general, this dimensional model of CDA has the aim to introduce the challenging principles because it was the best principle to understand and has related to social context. 


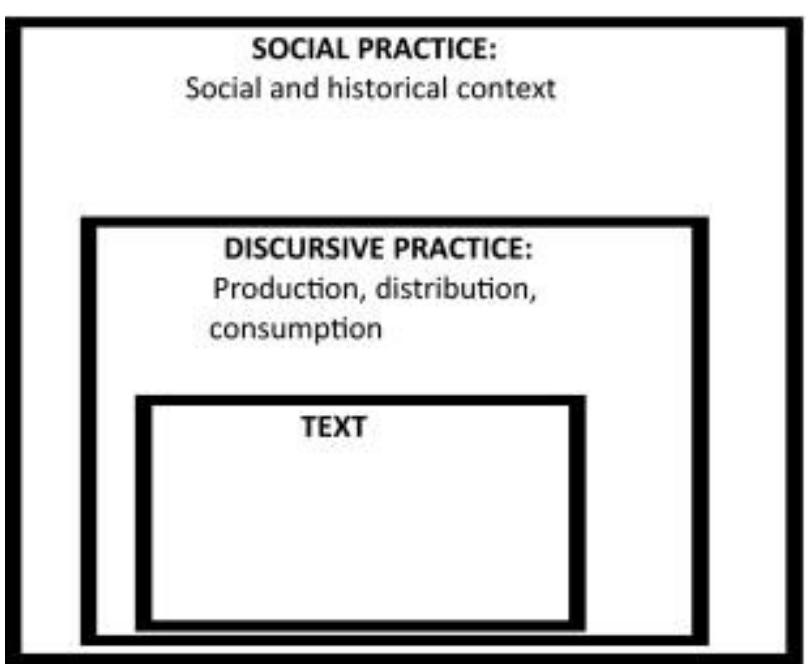

Figure 2.2.1 Three-Dimensional Model of Fairclough's Critical Discourse Analysis

\section{Method}

In undertaking the research review, the first thing is searching the database using the internet in Google Scholar and other electronic journal databases. From the electronic journal databases, this study will select studies related to critical discourse analysis. This method is known as library research, and this study chose this on the justification that Google Scholar and other electronic journal databases offer researchers the opportunity to extract high-quality studies that are openly accessible. The framework of the way this study was conducted is shown on Figure 3.1.

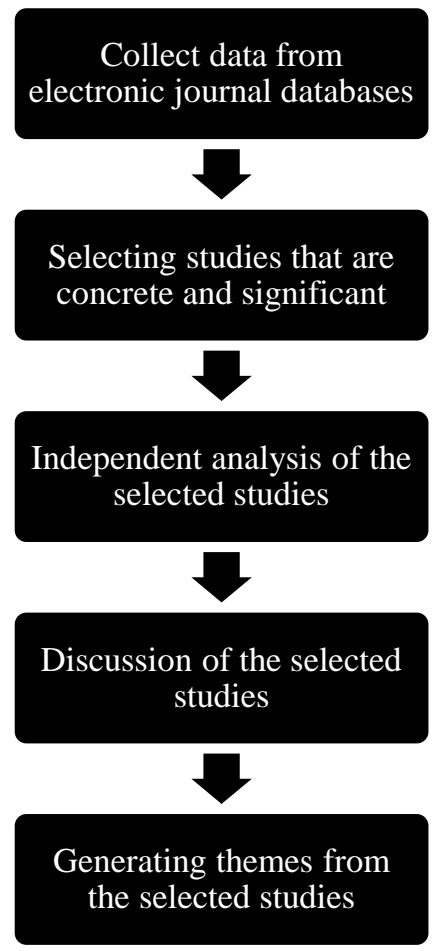

Figure 3.1 Methodological Framework
The data collection was successful as the databases explored in this study were free and easy to access. In exploring the databases, the period of study publication has been limited from 2015 to 2020 . The keywords of searching this research were critical discourse analysis, discourse analysis, and media studies to support this research.

Within multiple electronic journal databases, it selected again which one of those studies is real, correct and unique. Initially, there are 25 related studies were downloaded from Google Scholar and other open access electronic journal databases. From these 25 related studies, this study selected 10 research studies on the basis that they have a concrete framework and substantial content. Then, those research studies were read, reviewed and analyze independently, then together in multiple discussions among the researchers. In the end, this study determined three themes in critical discourse analysis application, i.e. economic, political, and social contexts.

\section{Results \& Discussion}

From many databases that have searched, it was getting the politic ideology about the connotation word. It has a different meaning from the truth one about the leader's character in social. A group of powerless people sometimes are not able to debate or comment on the issues of politics or an event.

Critical discourse analysis as one of the applied linguistic field has been found in many kinds and genres on analyzing the critical phenomena that appearance of a new ideology, discrimination of social classes, genders, and races. All those vital phenomena are performed in mass media of public life. The mass media can present in many types of it, such as newspaper, advertisement, and radio with the current issues at that time. On applicating the Fairclough's Framework of CDA, there are some themes of cases explained like economics, politicals, and social contexts.

\subsection{Economic Context}

First cases are discussed beauty products "Fair \& Lovely" discourse and the strategies used in exploiting all women. The discourse used in beauty products is perceived can getting a positive ideology of women to respond to this advertisement of beauty product. Yet, many consumers failed to notice their mind about the negative structures discourse of the beauty product. For instance, "Fair \& Lovely" product using catchy words as 'face polish', 'daily fairness', and 'night fairness' to create an interesting ideology on woman's mind. That catchy words make women think of using this product will help their face forever and that words can manipulate the woman's belief (Iqbal, Danish, and Tahir, 2014)

Other cases, it is has examined the power of the product and the ideas through advertisements which indirectly influenced the consumers. Next, Beauty product of "Nivea" that represented the word as "Goodbye Cellulite." That 
word makes an ideology of woman, by using this product can eliminate all cellulite in woman's body. With the attractive name from Nivea also manipulate the woman's mind and enable consumers to trust and believe the product entirely (Vahid \& Esmae'li, 2012).

Kaur, Arumugam, \& Yunus (2013) also explored the discourse on the beauty product advertisement as part of the social process from the social practice of the language. Therefore, from two cases above, a woman with smooth skin and slim's body have more power in their community than an ordinary woman who does not has the "commonly desired" characteristics.

\subsection{Political Context}

First cases in political aspects, from Zhang that already analyzed in "The New York Times" American Newspaper about political context between Irak and America. By using the three-dimensional framework of Fairclough, Zhang got the result that a positive ideology comes from the Bush government because he had a liberator and friendly behaviour. In contrast, Saddam Hussain did not have the same his government has a contrary ideology from the people (Zhang, 2014).

Other cases, in the "Indonesia Daily Newspapers" about the building's construction of the Corruption Eradication Commission (CEC). These cases have two parties, CEC and Parliament, a negative ideological is gotten by Parliament because they strongly opposed the building's construction of the CEC then many members of Parliament have believed to corrupted (Darmayanti \& Riyanto, 2013).

\subsection{Social Context}

The first case in social is from "Time Magazine" that investigated Americans on the Muslims ideological. For American people, Muslims are known as 'terrorists' that can threaten them. The statement from Talbott can be an example of this phenomenon as "Laws of Muslim religious against impiety and immodesty" (Talbott 1991). It shows that Muslims are extremist, immodest, and violent. Therefore, contributing to a perspective of critical that reflects the negativism of the Muslims in the world (Iqbal, Danish, \& Iqbal, 2014).

\section{Conclusion}

From this review research and literature, it was shown that Critical Discourse Analysis (CDA) has been popular in discourse studies field because the application CDA in this era is increased than 20 years in the past. The increasing studies have applied this field in investigating interaction, social context, and discursivity of text, in exploring the relationship between ideology and language, and analyzing what ideology is more dominant in CDA.

However, in CDA, mass media play an important role. The mass media is one thing that supports the increasing number of CDA in this era. Therefore, mass media plays a vital role in the proliferation of CDA's application in any contexts, particularly in the three themes that this study found, i.e. economic, political, and social contexts.

\section{References}

Brown, G. (1995). Speakers, listeners and communication: Explorations in discourse analysis. Cambridge University Press.

Carbaugh, D. (2007). Cultural discourse analysis: Communication practices and intercultural encounters. Journal of intercultural communication research, 36(3), 167-182.

Darmayanti, N., \& Riyanto, S. (2013). Critical discourse analysis of reporting on" Saweran for KPK Building" in media Indonesia Daily Newspaper. International Journal of Linguistics, 5(4), 213.

Derin, T., Deliani, S., Fauziah, N., Afifah, N., \& Hamuddin, B. (2019). Indonesians' Tendency to Refer Abbreviation as Acronym: Types of Abbreviation as Word Formation Process. Globish: An EnglishIndonesian Journal for English, Education, and Culture, 8(2).

Fairclough, N. (1992). Discourse and social change (Vol. 10). Cambridge: Polity press.

Fairclough, N. (2013). Critical discourse analysis: The critical study of language. Routledge.

Fairclough, N., \& Kress, G. (1993). Critical discourse analysis: manuscript.

Hamuddin, B. (2015). Discourse on Media: Bringing Hot News into ELT's Classroom Discussion. Proceedings of ISELT FBS Universitas Negeri Padang, 3, 87-95.

Iqbal, A., Danish, M. H., \& Iqbal, F. (2014). Critical discourse analysis of attributive words used with the word Muslim: A corpus based study. International Journal of Linguistics, 6(4), 1

Iqbal, A., Danish, M. H., \& Tahir, M. R. (2014). Exploitation of women in beauty products of Fair and Lovely: A critical discourse analysis study. International Journal on Studies in English Language and Literature, 2(9), 122-131.

Kaur, K., Arumugam, N., \& Yunus, N. M. (2013). Beauty product advertisements: A critical discourse analysis. Asian Social Science, 9(3), 61.

Kaur, K., Arumugam, N., \& Yunus, N. M. (2013). Beauty product advertisements: A critical discourse analysis. Asian Social Science, 9(3), 61.

Nordquist, R. (2020, January 28). Discourse Analysis: Observing the Use of Language. Thoughtco. Retrieved from: 
https://www.thoughtco.com/discourse-analysis-orda-1690462

Smith, P., \& Bell, A. (2007). Unravelling the web of discourse analysis. Media studies: Key issues and debates, 78-100.

Talbott, S. (1991). God and man in the Gulf. Time, 137(11), 35-35.

Vahid, H., \& Esmae'li, S. (2012). The power behind images: Advertisement discourse in focus. International journal of Linguistics, 4(4), 36.

Van Dijk, T. A. (1985). Handbook of discourse analysis. In Discourse and dialogue.

van Dijk, T. A. (Ed.). (2011). Discourse and communication: New approaches to the analysis of mass media discourse and communication (Vol. 10). Walter de Gruyter.

Wodak, R. (2001). What CDA is about-a summary of its history, important concepts and its developments. Methods of critical discourse analysis, 1, 1-13.

Yunira, S., Pradina, S., Sumbayak, M., Putri, N. S., \& Derin, T. (2019). Re-Visits the Grand Theory of Geoffrey Leech: Seven Types of Meaning. REiLA: Journal of Research and Innovation in Language, 1(3), 95-100.

Zhang, M. (2014). A critical discourse analysis of political news reports. Theory and practice in language studies, 4(11), 2273. 